\title{
EVALUASI FORMULA KRIM MINYAK BIJI DELIMA (PUNICA GRANATUM L.) DAN UJI AKTIVITAS ANTIOKSIDAN DENGAN METODE $\beta$-CAROTENE BLEACHING
}

\author{
Nur Mita ${ }^{1 * *}$, Sasanti Tarini D. ${ }^{2}$, Sophi Damayanti ${ }^{3}$ \\ ${ }^{1}$ Laboratorium Penelitian dan Pengembangan FARMAKA TROPIS Fakultas Farmasi \\ Universitas Mulawarman, Samarinda, Kalimantan Timur \\ ${ }^{2}$ Kelompok Keilmuan Farmasetika, Sekolah Farmasi ITB \\ ${ }^{3}$ Kelompok Keilmuan Farmakokimia, Sekolah Farmasi ITB \\ *email :mithafarma@gmail.com
}

\begin{abstract}
ABSTRAK
Minyak biji delima memiliki aktivitas antioksidan kuat, sehingga berpotensi untuk diformulasi menjadi sediaan antioksidan topikal. Tujuan penelitian ini adalah untuk mengevaluasi formula sediaan krim minyak biji delima dan menguji aktivitas antioksidan dari sediaan tersebut. Krim $\mathrm{a} / \mathrm{m}$ diformulasi menggunakan emulgator Tween 80- Span 80. Evaluasi sediaan meliputi pemeriksaan $\mathrm{pH}$ dan viskositas sediaan yang disimpan selama 4 minggu pada suhu kamar, stabilitas fisik dengan metode Freeze Thaw sebanyak 4 siklus dimana 1 siklus terdiri dari 48 jam pada suhu $4^{\circ} \mathrm{C}$ dan 48 jam pada suhu $40^{\circ} \mathrm{C}$. Potensi antioksidan diuji dengan metode $\beta$ Carotene Bleaching. Formula krim yang mengandung minyak biji delima 1\% stabil secara fisik. Hasil uji efek antioksidan menunjukkan persen penghambatan minyak biji delima murni dan minyak biji delima dalam bentuk krim terhadap penurunan warna $\beta$-Carotene berturutturut adalah $73,41 \%$ dan $52,80 \%$. Berdasarkan hasil penelitian ini dapat disimpulkan bahwa aktivitas antioksidan minyak biji delima dalam bentuk krim mengalami penurunan 0,3 kali.
\end{abstract}

Kata kunci: krim, minyak biji delima, antioksidan, $\beta$-Carotene Bleaching

\begin{abstract}
Pomegranate seed oil has a potent antioxidant activity that is potential to be formulate into topical antioxidant dosage form. The purpose of this study is to formulate cream of pomegranate seed oil that physically stable, however have antioxidant activity. Cream w/o was formulated using Tween 80 - Span 80 as emulsifier. Evaluation of cream products includes determining $\mathrm{pH}$ and viscosity of the preparations stored for 4 weeks at room temperature, physical stability test by Freeze Thaw method which was carried out for 4 cycles in where 1 cycle consists of 48 hours at $4^{\circ} \mathrm{C}$ and 48 hours at $40^{\circ} \mathrm{C}$. Antioxidant activity was tested by $\beta$-carotene bleaching method. The results of the research showed that all cream formulas containing pomegranate seed oil 1\% were physically stable and can increase the comfortness in use on the skin. The antioxidant test results showed antioxidant activity of pure pomegranate seed oil and pomegranate seed oil as formulated in creams have antioxidant capacity with inhibition percentage of $73.41 \%$ and $52.80 \%$, respectively. Based on these
\end{abstract}


results it can be concluded that the antioxidant activity of pomegranate seed oil in cream decreased 0,3 times.

Keywords: cream, pomegranate seed oil, antioxidant, $\beta$-Carotene Bleaching

\section{PENDAHULUAN}

Radikal bebas yang merupakan produk samping dari metabolisme normal seluler dapat mempercepat proses penuaan alami tubuh. Radikal bebas dapat juga terbentuk oleh faktor-faktor lingkungan eksternal seperti paparan sinar UV, asap rokok dan polusi udara. Terpapar radiasi UV dalam waktu lama akan menyebabkan kerusakan kulit, sunburn, photoaging, dan dapat menimbulkan kanker kulit [1].

Radikal bebas dapat dinetralisir melalui mekanisme pertahanan alami tubuh dengan menggunakan antioksidan. Antioksidan ditemukan dalam dua bentuk yaitu antioksidan enzimatik dan nonenzimatik. Superokside dismutase (SOD), katalase, dan glutathione peroksidase adalah beberapa dari antioksidan enzimatik alami yang digunakan oleh tubuh. Adapun antioksidan non-enzimatik antara lain polifenol, Vitamin E (tokoferol), Vitamin $\mathrm{C}$ (asam askorbat), vitamin A (beta karoten) dan lainnya [1].

Minyak biji delima menunjukkan aktivitas antioksidan dengan kekuatan yang sebanding dengan butylated hydroxyanisole (BHA) dan teh hijau, serta secara signifikan daya antioksidan minyak biji delima lebih tinggi dibandingkan anggur merah. Minyak biji delima mengandung polifenol dan beberapa asam lemak antara lain asam palmitat, asam stearat, asam oleat, asam linoleat, dan terutama punicid acid. Aktivitas antioksidan minyak biji delima ditentukan dengan mengukur oksidasi berpasangan dari asam linoleat dan $\beta$-carotene [2]. Selain itu, ditemukan pula kandungan tinggi $\alpha$-tokoferol dan $\gamma$-tokoferol pada minyak biji delima [3]. Tokoferol yang teridentifikasi diperkirakan berperan utama sebagai antioksidan dari minyak biji delima [4].

Pada penelitian ini minyak biji delima juga dibuat dalam bentuk sediaan krim. Krim merupakan sistem emulsi yang memiliki konsistensi semisolida yang merupakan sistem dispersi cair-cair yang tidak bercampur dan secara termodinamika tidak stabil sehingga diperlukan stabilisator yang disebut emulgator. Tipe krim a/m dipilih karena kandungan minyak biji delima bersifat lipofilik, sehingga pelepasan zat aktif akan lebih mudah ketika berada dalam fasa eksternal dalam bentuk minyak. Pada penelitian ini diharapkan dapat dihasilkan sediaan topikal krim minyak biji delima yang stabil secara fisik dan memiliki khasiat antioksidan.

\section{ALAT DAN BAHAN}

Alat-alat yang digunakan yaitu Ultra Turax T 25 (Janke\& Kunkel IKA Labortechnik), spektrofotometri UV-Vis (Beckman DU-7500i), $\Phi 50$ pHmeter (Beckman), Viskometer Brookfield (DV $\mathrm{I}+$ ), timbangan gram (Santorius), timbangan miligram (AG204), oven, lemari es, penangas air, dan seperangkat alat gelas.

Bahan yang digunakan antara lain air suling, aquabides (PT. Ipha Laboratories), asam linoleat (Sigma), $\beta$ carotene (Calbiochem), etanol (Bratachem), kloroform, metil paraben, minyak biji delima (Aksuvital, Turki), propilen glikol (Bratachem), propil paraben, setostearil alkohol (Bratachem), Span 80 (Bratachem), Tween 40 (Bratachem), Tween 80 (Bratachem), Virgin Coconut Oil (VCO) (SITH ITB). 


\section{METODE PENELITIAN}

\section{Karakterisasi Minyak Biji Delima}

Karakterisasi minyak biji delima meliputi bentuk, warna, bau, kelarutan, bilangan asam, bilangan iodine, bilangan penyabunan dan kadar air. Beberapa pengujian dilakukan di laboratorium PT. Sucofindo, Jakarta.

\section{Uji Potensi Antioksidan dengan Metode Beta-Carotene Bleaching (BCB)}

Sebanyak $1 \mathrm{mg} \quad \beta$-carotene dilarutkan dengan kloroform hingga 10 $\mathrm{mL}$, kemudian $200 \mu \mathrm{L}$ larutan $\beta$-carotene ditambahkan dengan $20 \mu \mathrm{L}$ asam linoleat dan $200 \mu \mathrm{L}$ Tween 40. Setelah penguapan hingga kering dalam vakum pada $50^{\circ} \mathrm{C}$ selama 5 menit dengan rotary evaporator, $50 \mathrm{~mL}$ aquabides ditambahkan dan campuran tersebut diemulsifikasi selama 2 menit untuk membentuk emulsi A. Sebanyak $2 \mathrm{~mL}$ larutan stok minyak biji delima sebagai antioksidan (konsentrasi larutan stok adalah 100 ppm dalam etanol) dicampurkan dengan $5 \mathrm{~mL}$ emulsi $\mathrm{A}$ dan dimasukkan dalam kuvet untuk diukur absorbansinya. Disiapkan pula kontrol yang terdiri dari $2 \mathrm{~mL}$ etanol dan $5 \mathrm{~mL}$ emulsi A. Pembacaan seluruh sampel dilakukan secepatnya $(\mathrm{t}=0)$ dan pada interval 15 menit selama 90 menit dengan Spektrofotometer UV-Vis pada panjang gelombang $460 \mathrm{~nm}$. Kuvet-kuvet ditermostat pada suhu $50^{\circ} \mathrm{C}$ diantara pengukuran (2). Persen penghambatan dihitung dari data dengan rumus:

$$
\% \text { Penghambatan }=\frac{\left(S_{90}-A_{90}\right)}{A_{0}-A_{90}} \times 100 \%
$$

Dimana $\mathrm{S}_{90}$ adalah absorbansi dari antioksidan pada $\mathrm{t}=90$ menit, $\mathrm{A}_{90}$ adalah absorbansi dari kontrol pada $\mathrm{t}=90$ menit, dan $\mathrm{A}_{0}$ adalah absorbansi dari kontrol pada $\mathrm{t}=0$ menit [5].

\section{Formulasi Sediaan Krim Minyak Biji Delima}

Krim dibuat dengan cara memanaskan fase minyak dan fase air masing-masing sampai suhu $70^{\circ} \mathrm{C}$ di atas penangas air. Fase minyak terdiri atas VCO, setostearil alkohol, Span 80, propil paraben. Fase air dibuat dengan melarutkan metil paraben dalam air yang telah dipanaskan hingga $70^{\circ} \mathrm{C}$ kemudian ditambahkan propilen glikol dan Tween 80 . Kedua fase dicampurkan dan diaduk dalam keadaan panas menggunakan Ultra Turax dengan kecepatan pengadukan 8000 rpm selama 2 menit. Bahan aktif minyak biji delima ditambahkan ke dalam basis pada suhu $50^{\circ} \mathrm{C}$ dan diaduk dengan kecepatan $8000 \mathrm{rpm}$ selama 2 menit.

\section{Evaluasi Stabilitas Fisik Krim}

Evaluasi meliputi organoleptik, viskositas, $\mathrm{pH}$, dan stabilitas fisik krim dengan freeze thaw. Evalausi organoleptik ditentukan dengan mengamati perubahan bau, warna, dan adanya pertumbuhan jamur pada sediaan selama penyimpanan. Sediaan krim (100 gram) ditempatkan dalam suhu kamar selama 4 minggu. Viskositas dan $\mathrm{pH}$ diamati setiap minggu selama 4 minggu dengan pengamatan awal pada 48 jam pertama.

Evaluasi stabilitas fisik dengan metode freeze thaw ditentukan dengan menyimpan sediaan selama 2 hari pada suhu $4^{\circ} \mathrm{C}$ kemudian disimpan pada suhu 40 ${ }^{\circ} \mathrm{C}$ selama 2 hari. Pengujian dilakukan selama 4 siklus.

\section{Uji Aktivitas Antioksidan Krim Minyak Biji Delima}

Sampel uji terdiri dari KM yaitu formula krim minyak biji delima, $\mathrm{K}_{1}$ yaitu formula basis krim dan $\mathrm{D}_{1}$ yaitu larutan minyak biji delima dalam etanol 100 ppm. Uji aktivitas antioksidan dilakukan dengan konsentrasi sebesar $100 \mathrm{ppm}$. 
Formula $\mathrm{KM}$ dan $\mathrm{K}_{1}$ masingmasing ditimbang $0,5 \mathrm{~g}$ (mengandung $5 \mathrm{mg}$ minyak biji delima) kemudian diencerkan dengan etanol dalam labu ukur $50 \mathrm{~mL}$ (setara dengan 100 ppm minyak biji delima). $\mathrm{D}_{1}$ dibuat dengan cara minyak biji delima ditimbang sebanyak $100 \mathrm{mg}$ kemudian diencerkan dengan etanol dalam labu ukur $50 \mathrm{~mL}$ (setara dengan 2000 ppm minyak biji delima), kemudian dipipet 5 $\mathrm{mL}$ dan diencerkan lagi dengan etanol dengan labu ukur $10 \mathrm{~mL}$ (setara dengan $1000 \mathrm{ppm}$ ), lalu dipipet $1 \mathrm{~mL}$ dan diencerkan lagi dengan etanol menggunakan labu ukur $10 \mathrm{~mL}$ (setara dengan 100 ppm minyak biji delima).

Sebanyak $1 \mathrm{mg} \quad \beta$-carotene dilarutkan dengan kloroform hingga 10 $\mathrm{mL}$, kemudian $200 \mu \mathrm{L}$ larutan $\beta$-carotene ditambahkan dengan $20 \mu \mathrm{L}$ asam linoleat dan $200 \mu \mathrm{L}$ Tween 40. Setelah penguapan hingga kering dalam vakum pada $50^{\circ} \mathrm{C}$ selama 5 menit dengan rotary evaporator, $50 \mathrm{~mL}$ aquabides ditambahkan dan campuran tersebut diemulsifikasi selama 2 menit untuk membentuk emulsi A. Masingmasing $2 \mathrm{~mL}$ larutan $\mathrm{KM}, \mathrm{K}_{1}$ dan $\mathrm{D}_{1}$ dicampurkan dengan $5 \mathrm{~mL}$ emulsi $\mathrm{A}$ dan dimasukkan dalam kuvet untuk diukur absorbansinya. Disiapkan pula kontrol (tanpa antioksidan) yang terdiri dari masing $2 \mathrm{~mL}$ etanol $\left(\mathrm{D}_{0}\right.$ untuk kontrol dari $\mathrm{D}_{1}$ dan $\mathrm{K}_{0}$ untuk krim) dengan $5 \mathrm{~mL}$ emulsi A. Pembacaan seluruh sampel dilakukan secepatnya $(\mathrm{t}=0)$ dan pada interval 15 menit selama 90 menit dengan Spektrofotometer UV-Vis pada panjang gelombang $460 \mathrm{~nm}$. Kuvet-kuvet ditermostat pada suhu $50^{\circ} \mathrm{C}$ diantara pengukuran.

\section{HASIL DAN PEMBAHASAN}

Penelitian ini diawali dengan melakukan karakterisasi terhadap bahan aktif yaitu minyak biji delima. Hasil pemeriksaan karakteristik minyak biji delima dapat dilihat pada Tabel 1.

Tabel 1 Karakterisasi minyak biji Delima (Punica grantum L.)

\begin{tabular}{lll}
\hline Parameter & Satuan & Hasil \\
\hline Bentuk & & Cairan agak kental \\
Warna & & Kuning transparan \\
Bau & & Khas (kurang menyenangkan) \\
Kelarutan & & Praktis tidak larut dalam air, sangat larut dalam \\
& & etanol $(1: 2)$, kloroform $(1: 2)$, VCO $(1: 1)$ \\
Bilangan asam sebagai oleic* & $\%$ & 0.99 \\
Bilangan iodine* & & 143.01 \\
Bilangan penyabunan* & & 207.84 \\
Kadar air* & $\%$ & 0.06 \\
\hline
\end{tabular}

*: dilakukan pengujian di PT. Sucofindo (Persero), Sertifikat No. 50787/BBBFAF

Selanjutnya dilakukan uji aktivitas antioksidan dari minyak biji delima dengan menggunakan metode $\beta$-Carotene Bleaching (BCB). Metode ini dipilih karena sangat baik digunakan untuk senyawa yang bersifat lipofilik seperti essential oil, termasuk minyak biji delima. Aktivitas antioksidan dengan metode $\mathrm{BCB}$ ditentukan berdasarkan kemampuan sampel uji antioksidan dalam menghambat penurunan intensitas warna kuning dari $\beta$ karoten karena pengaruh radikal bebas (hidroperoksid) yang terbentuk dari oksidasi asam linoleat akibat pemanasan. Uji aktivitas antioksidan dilakukan dengan mencampurkan $2 \mathrm{~mL}$ minyak biji delima (yang telah diencerkan dengan etanol hingga konsentrasi $100 \mathrm{ppm}$ ) dengan $5 \mathrm{~mL}$ 
emulsi A ( $\beta$-karoten, asam linoleat, Tween 40, aquabides). Disiapkan pula kontrol yaitu dengan mencampurkan $2 \mathrm{~mL}$ etanol dan $5 \mathrm{~mL}$ emulsi A. Masing-masing kemudian diukur absorbansinya dengan
Spektrofotometer UV-Vis pada panjang gelombang $460 \mathrm{~nm}$ pada menit ke-0, 15 , $30,45,60,75$, dan 90 . Selama pengukuran, suhu kuvet dipertahankan pada $50^{\circ} \mathrm{C}$.

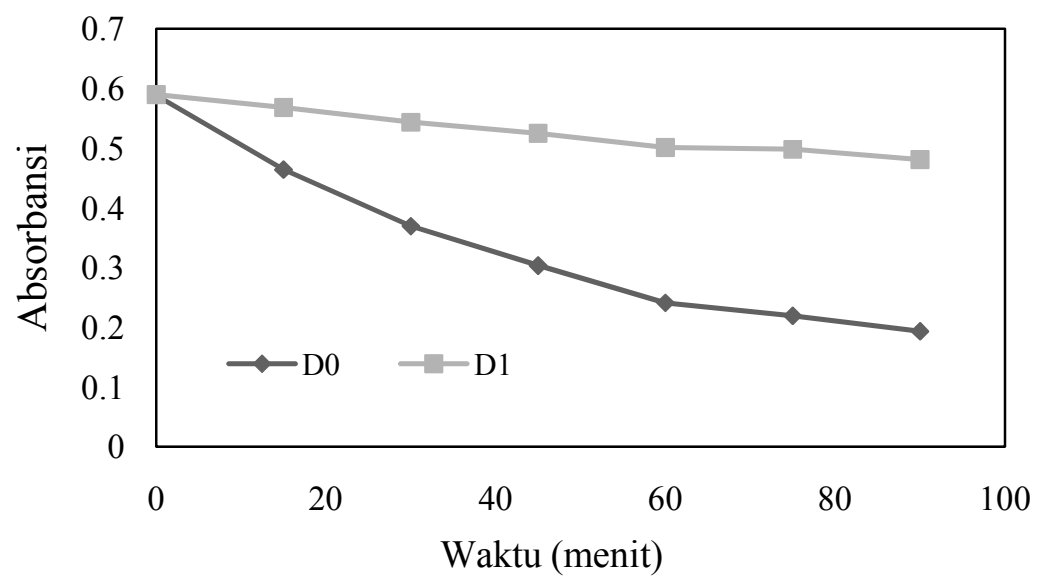

Gambar 1 Kurva hasil uji potensi antioksidan minyak biji delima dengan metode $\beta$-Carotene Bleaching

Keterangan : D0 : kontrol (etanol), dan D1 : minyak biji delima (100 ppm)

Dari hasil perhitungan potensi antioksidan minyak biji delima diperoleh bahwa persen penghambatannya terhadap penurunan intensitas warna beta-karoten adalah $73,14 \pm 0,693 \%$ pada konsentrasi 100 ppm dalam etanol. Hasil tersebut menunjukkan bahwa minyak biji delima memiliki aktivitas antioksidan kuat. Kapasitas antioksidan dengan metode BCB digolongkan menjadi tiga tingkat yaitu antioksidan kuat $(>70 \%)$, intermediate (40$70 \%)$, dan lemah $(<40 \%)[6]$.

Tabel 2 Orientasi basis krim dengan emulgator TEA-stearat

\begin{tabular}{lllll}
\hline Komposisi/\% & $\mathrm{A} 1$ & $\mathrm{~A} 2$ & $\mathrm{~A} 3$ & $\mathrm{~A} 4$ \\
\hline VCO & 40 & 40 & 40 & 40 \\
TEA & 2 & 2 & 1 & 1 \\
Asam Stearat & 4 & 6 & 5 & 6 \\
Air ad. & 100 & 100 & 100 & 100 \\
Pengamatan & Agak encer & Baik & Baik & Baik \\
pH & 8.42 & 8.23 & 8.14 & 8.05 \\
\hline
\end{tabular}

Keterangan:

A1 : Krim dengan perbandingan TEA- Asam sterat 1:2

A2 : Krim dengan perbandingan TEA- Asam sterat 1:3

A3 : Krim dengan perbandingan TEA- Asam sterat 1:5

A4 : Krim dengan perbandingan TEA- Asam sterat 1:6 
Formulasi krim diawali dengan orientasi basis yaitu emulgator kombinasi antara trietanolamin (TEA) dan asam stearat, yaitu pada Tabel 2. Asam stearat digunakan dalam krim sebagai zat pengemulsi untuk memperoleh konsistensi krim tertentu serta untuk memperoleh efek yang tidak menyilaukan mata. Jika stearat digunakan sebagai pengemulsi, maka umumnya TEA ditambahkan secukupnya agar bereaksi dengan asam stearat. Dari hasil orientasi tersebut semua formula menunjukkan $\mathrm{pH}$ sediaan yang terbentuk adalah di atas $\mathrm{pH} 8$ dan tidak memenuhi rentang $\mathrm{pH}$ kulit yaitu antara $\mathrm{pH} 4,5-6$ sehingga orientasi dengan menggunakan emulgator TEA-sterat tidak dilanjutkan.

Tabel 3 Orientasi basis krim dengan emulgator Tween 80 - Span 80

\begin{tabular}{|c|c|c|c|c|c|c|c|}
\hline Komposisi (\%) & $\mathrm{H}$ & I & $\mathrm{J}$ & $\mathrm{K}_{1}$ & $\mathrm{~K}_{2}$ & $\mathrm{~K}_{3}$ & $\mathrm{~K}_{4}$ \\
\hline$\overline{\mathrm{VCO}}$ & 40 & 40 & 40 & 40 & 40 & 40 & 40 \\
\hline Tween 80 & 3 & 3 & 4 & 5 & 5 & 5 & 5 \\
\hline Span 80 & & & & & & & \\
\hline Cetostearil Alkohol & 4 & 5 & 5 & 5 & 6 & 7 & 8 \\
\hline Propilen glikol & 10 & 10 & 10 & 10 & 10 & 10 & 10 \\
\hline Air ad. & 100 & 100 & 100 & 100 & 100 & 100 & 100 \\
\hline $\begin{array}{l}\text { Pengamatan } \\
\mathrm{pH}\end{array}$ & $\begin{array}{l}\text { encer } \\
6.07\end{array}$ & $\begin{array}{l}\text { memisah } \\
6.09\end{array}$ & $\begin{array}{l}\text { memisah } \\
6.11\end{array}$ & $\begin{array}{l}\text { baik } \\
6.15 \\
\end{array}$ & $\begin{array}{l}\text { Agak keras } \\
6.33\end{array}$ & $\begin{array}{l}\text { keras } \\
6.52 \\
\end{array}$ & $\begin{array}{l}\text { keras } \\
6.81 \\
\end{array}$ \\
\hline
\end{tabular}

Orientasi basis krim selanjutnya adalah dengan menggunakan emulgator Tween 80- Span 80. Adapun hasil pengamatan dapat dilihat pada tabel 3 . Pada formula ini digunakan minyak kelapa murni (VCO) karena kandungan asam lemak (terutama asam laurat dan asam oleat) dalam VCO bersifat melembutkan kulit sehingga dapat digunakan sebagai bahan pembawa sediaan obat. Selain itu, VCO juga berperan sebagai peningkat penetrasi melalui mekanisme peningkatan hidrasi kulit dengan cara berinteraksi dengan lipid (mortar) pada stratum korneum sehingga meningkatkan permeabilitas stratum korneum. Selain itu VCO digunakan sebanyak 40\% sebagai fase minyak karena diharapkan terbentuk $\mathrm{krim}$ tipe $\mathrm{a} / \mathrm{m}$. Setostearil alkohol digunakan dalam formula karena berfungsi sebagai emolien dan peningkat konsistensi dalam sediaan krim. Sedangkan propilen glikol dalam formula krim berfungsi sebagai humektan.
Formula awal dibuat dengan menggunakan Tween 80-Span 80 3\% dan setostearil alkohol 4\% yaitu formula $\mathrm{H}$. Dari hasil pengukuran diperoleh bahwa $\mathrm{pH}$ sediaan krim pada formula $\mathrm{H}$ yaitu 6,05 . $\mathrm{pH}$ tersebut masih masuk dalam interval $\mathrm{pH}$ kulit.

Pengembangan selanjutnya
dilakukan dengan memvariasikan
konsentrasi Tween 80 -Span 80 sebagai emulgator yaitu 3, 4, dan 5\%. Dari hasil pengamatan didapatkan bahwa pada formula dengan konsentrasi Tween 80Span 80 3\% dan 4\% mengalami pemisahan fase setelah disentrifugasi dengan kecepatan 3750 rpm selama 30 menit sedangkan formula dengan Tween 80 -Span $805 \%$ tetap stabil. Dengan demikian dipilih konsentrasi emulgator 5\% untuk dikembangkan selanjutnya dalam formula sediaan krim.

Setelah itu dilakukan orientasi terhadap viskositas dari sediaan untuk mendapatkan konsistensi yang baik, 
sehingga nyaman dalam penggunaan. Pada orientasi ini divariasikan konsentrasi dari setostearil alkohol yaitu 5, 6, 7, dan $8 \%$. Berdasarkan hasil pengamatan diperoleh bahwa konsistensi basis yang baik diperoleh pada konsentrasi setostearil alkohol 5\%, sedangkan formula dengan konsentrasi setostearil alkohol 6, 7, dan 8\% menghasilkan krim dengan konsistensi yang keras. Dari hasil orientasi di atas maka dipilih formula $\mathrm{K}_{1}$ sebagai basis krim untuk ditambahkan bahan aktif sebagai formula akhir. Formula akhir krim, sebagaimana ditunjukkan pada Tabel 4, kemudian dievaluasi stabilitas dan diuji aktivitas antioksidannya.

Tabel 4 Formulasi akhir krim minyak biji Delima 1\%

\begin{tabular}{lll}
\hline Komposisi / \% & $\mathrm{K}_{1}$ & $\mathrm{KM}$ \\
Minyak biji delima & - & 1 \\
VCO & 40 & 40 \\
Tween 80 & 5 & 5 \\
Span 80 & & \\
Setostearil alkohol & 5 & 5 \\
Propilen glikol & 10 & 10 \\
Metil paraben & 0.18 & 0.18 \\
Propil paraben & 0.02 & 0.02 \\
Air & Ad. 100 & Ad. 100 \\
Pengamatan & Baik & Baik \\
pH & 6.15 & 5.78 \\
\hline
\end{tabular}

Keterangan:

$\mathrm{K}_{1} \quad$ : Krim tanpa minyak biji delima (basis)

KM : Krim minyak biji delima $1 \%$

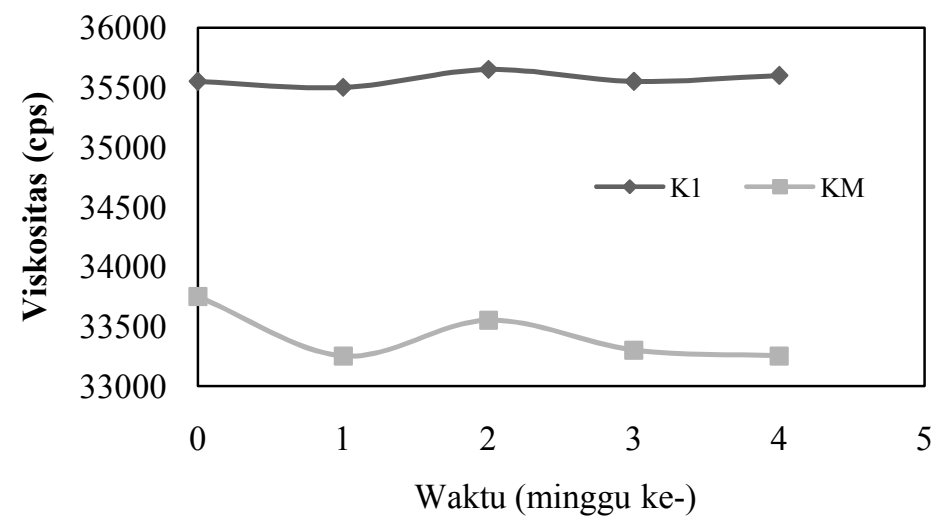

Gambar 2 Profil viskositas sediaan selama 4 minggu

Viskositas dari formula $\mathrm{K}_{1}$ dan $\mathrm{KM}$ diukur pada kecepatan 2,5 rpm dengan menggunakan spindel S28. Hasil pengukuran (Gambar 2) menunjukkan bahwa viskositas semua formula tetap stabil selama evaluasi 4 minggu. Hasil evaluasi $\mathrm{pH}$ menunjukkan bahwa kedua sediaan memiliki $\mathrm{pH}$ sediaan sekitar 5 dan 6. Hal ini disebabkan karena bahan-bahan tambahan yang digunakan pada pembuatan 
formula akan memberikan $\mathrm{pH}$ sekitar 5 s.d. 7. Gambar 3 menunjukkan bahwa $\mathrm{pH}$ sediaan tetap stabil selama 4 minggu. Hal tersebut menunjukkan bahwa sediaan stabil secara kimia, tidak terjadi reaksi atau interaksi kimia antara bahan-bahan yang terkandung dalam sediaan.

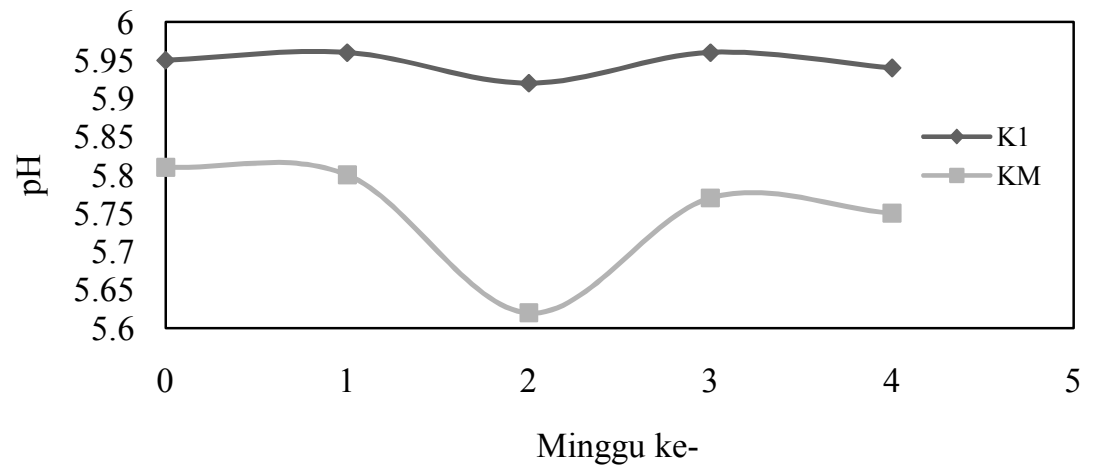

Gambar 3 Profil $\mathrm{pH}$ sediaan selama 4 minggu

Tabel 5 Uji stabilitas fisik sediaan dengan metode Freeze-thaw selama 1 bulan

\begin{tabular}{lcccc}
\hline Formula & \multicolumn{4}{c}{ Pengamatan siklus ke- } \\
\hline & 1 & 2 & 3 & 4 \\
$\mathrm{~K}_{1}$ & - & - & - & - \\
$\mathrm{KM}$ & - & - & - & - \\
\hline
\end{tabular}

- : sediaan tidak berubah dan tetap stabil

Stabilitas fisik sediaan krim dilakukan dengan metode freeze-thaw. Sediaan krim $\mathrm{K}_{1}$ dan $\mathrm{KM}$ tetap stabil selama empat siklus freeze-thaw, sebagaimana ditunjukka pada Tabel 5 . Sediaan tidak mengalami perubahan warna, tetap homogen, dan tidak mengalami pemisahan fasa.

Berdasarkan hasil karakterisasi sebelumnya, diketahui bahwa minyak biji delima memiliki bau khas yang kurang menyenangkan. Setelah minyak biji delima diformulasi dalam bentuk sediaan krim, ternyata diperoleh bahwa bentuk sediaan krim mampu menutupi bau dari minyak biji delima. Hal ini menunjukkan bahwa formula mikroemulsi dan krim minyak biji delima dapat meningkatkan kenyamanan dalam penggunaan.

Penelitian dilanjutkan dengan uji potensi antioksidan dari sediaan krim. Pemeriksaan aktivitas antioksidan terhadap sediaan krim $\mathrm{KM}$ dan $\mathrm{K}_{1}$ dilakukan dengan mencampurkan $2 \mathrm{~mL}$ sediaan yang telah diencerkan dengan etanol hingga konsentrasi minyak biji delima (KM) dalam etanol sebesar 100 ppm dengan 5 $\mathrm{mL}$ emulsi A ( $\beta$-karoten, asam linoleat, Tween 40, dan aquabides) kemudian diukur absorbansinya. Setelah dilakukan pengukuran kemudian dilakukan pengenceran kembali pada sampel uji (KM) hingga diperoleh konsentrasi minyak biji delima setara dengan $10 \mathrm{ppm}$ dalam etanol. Hasil pengenceran ini kemudian diambil $2 \mathrm{~mL}$ dan dicampurkan dengan 5 $\mathrm{mL}$ emulsi A lalu diukur kembali absorbansinya sehingga diperoleh hasil seperti pada Gambar 4. Dari hasil pengukuran tersebut, kemudian dihitung aktivitas antioksidan dari $\mathrm{K}_{1}$ dan KM. Hasil perhitungan menunjukkan bahwa persen penghambatan dari krim $\mathrm{K}_{1}$ adalah $3.33 \pm \quad 0.043 \%$. Adapun persen 
penghambatan dari krim KM (setara dengan 10 ppm minyak biji delima) adalah $8.59 \pm 0.091 \%$ sehingga persen penghambatan untuk krim KM agar setara dengan 100 ppm minyak biji delima adalah $85,90 \pm 0.169 \%$, sedangkan persen penghambatan untuk krim $\mathrm{K}_{1}$ sebagai pembandingnya menjadi $33,10 \pm 0.151 \%$. Hasil ini menunjukkan bahwa sediaan krim KM (basis krim + minyak biji delima) memiliki aktivitas antioksidan kuat $(>70 \%)$ dan krim $\mathrm{K}_{1}$ (basis krim saja) juga memiliki aktivitas antioksidan meskipun tergolong lemah $(>40 \%)$. Adanya aktivitas antioksidan pada krim $\mathrm{K}_{1}$ disebabkan karena adanya VCO hingga $40 \%$ dalam basis krim yang digunakan. Setelah nilai persen penghambatan krim KM (basis krim + minyak biji delima) dikurangkan dengan nilai persen penghambatan dari krim $\mathrm{K}_{1}$ (basis pembandingnya) maka dapat diperoleh nilai persen penghambatan untuk bahan aktif sediaan yaitu minyak biji delima (setara $100 \mathrm{ppm}$ ) sebesar 52,80\%. Hasil tersebut menunjukkan bahwa aktivitas antioksidan minyak biji delima pada sediaan krim lebih rendah dibandingkan dengan hasil pengukuran aktivitas antioksidan pada minyak biji delima sebelumnya $\left(D_{1}\right)$ yaitu $73,41 \%$ pada konsentrasi yang sama (100 ppm minyak biji delima). Hal ini menunjukkan bahwa aktivitas antioksidan minyak biji delima mengalami penurunan setelah diformulasi dalam bentuk sediaan krim sebagaimana ditunjukkan melalui grafik pada Gambar 5. Penurunan tersebut disebabkan karena bahan aktif (minyak biji delima) larut dalam VCO pada basis krim dan terperangkap dalam matriks basis krim sehingga mempengaruhi pengukuran dalam uji aktivitas antioksidan yang dilakukan.

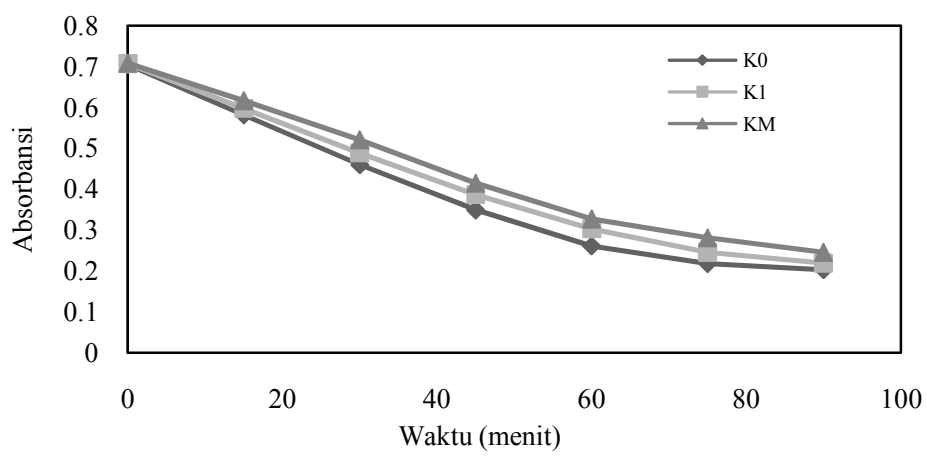

Gambar 4 Profil hasil uji aktivitas antioksidan krim minyak biji Delima dengan metode $\beta$ carotene bleaching

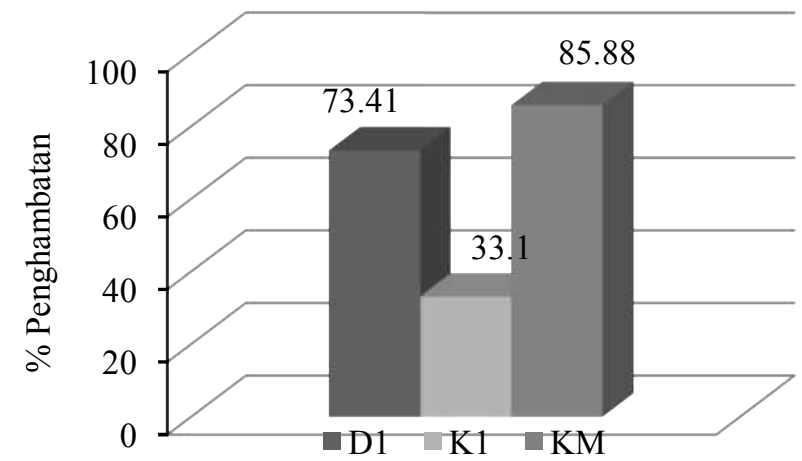

Gambar 5 Perbandingan potensi antioksidan dari minyak biji delima $\left(D_{1}\right)$ dan sediaan krim $\left(\mathrm{K}_{1}\right.$ dan $\left.\mathrm{KM}\right)$ dengan metode $\beta$-carotene bleaching 
Tabel 6 Perbandingan potensi antioksidan dengan metode $\beta$-carotene bleaching

\begin{tabular}{ccc}
\hline Sampel Uji & Konsentrasi Minyak biji delima $(\mathrm{ppm})$ & \% Penghambatan \\
\hline $\mathrm{D}_{1}$ & 100 & $\mathbf{7 3 . 4 1} \pm \mathbf{0 . 6 9 3}$ \\
$\mathrm{K}_{1}$ & 0 & $33.10 \pm 0.314$ \\
$\mathrm{KM}$ & 100 & $\mathbf{8 5 . 8 8} \pm \mathbf{0 . 1 6 9}$ \\
\hline
\end{tabular}

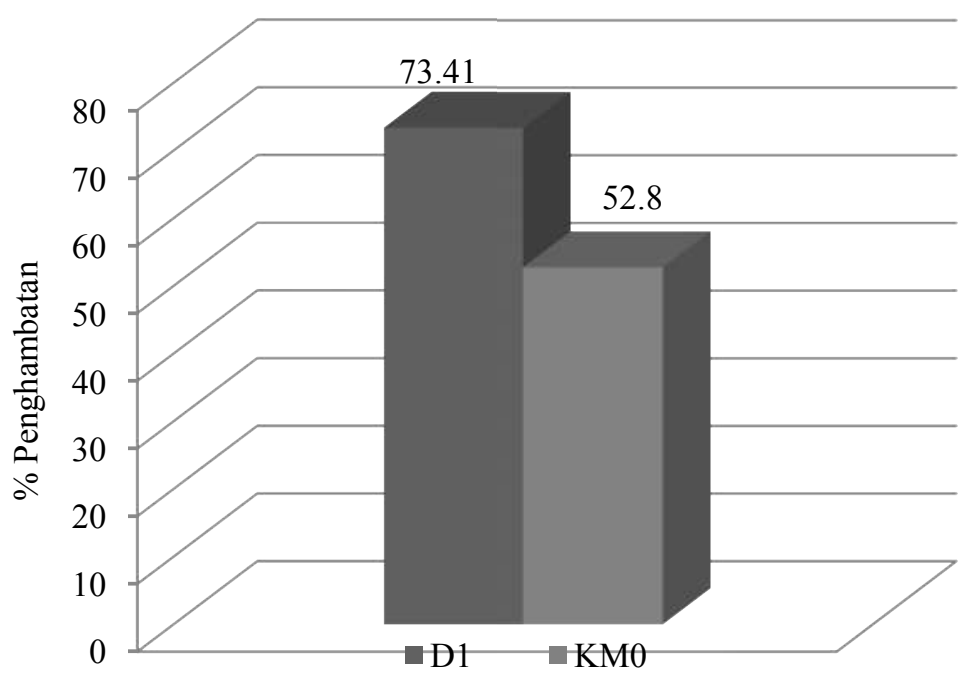

Gambar 6 Perbandingan aktivitas antioksidan minyak biji delima sebelum dibuat dalam sediaan $\left(\mathrm{D}_{1}\right)$ dan dalam sediaan $\operatorname{krim}\left(\mathrm{KM}_{0}\right)$

\section{KESIMPULAN}

Dari hasil penelitian dapat disimpulkan bahwa formula krim minyak biji delima $1 \%$ b/b stabil secara fisik, dapat meningkatkan kenyamanan dan menutupi bau dari minyak biji delima. Minyak biji delima memiliki aktivitas antioksidan kuat dengan persen penghambatan sebesar $73,41 \%$. Aktivitas antioksidan minyak biji delima dalam sediaan krim mengalami penurunan sebesar 0,3 kali.

\section{DAFTAR PUSTAKA}

1. Murad, M. (1999): Pomegranate Fruit Extract Composition for Treating Dermatological Disorder, United States Patent, Patent No. US 6, 800, 292 BI, USA
2. Schubert, S. Y, Lansky, E.P., Neeman, I. (1999): Antioxidant and Eucosanoid Enzyme Inhibition Properties of Pomegranate Seed Oil and Fermented Juice Flavonoid, Elsevier Journal of Ethnopharmacology 66, 11-17, Israel Institut of Technology, Israel

3. Pande G, Akoh CC (2009): Antioxidant Capacity and Lipid Characterization of Six Georgia-Grown Pomegranate Cultivars. J. Agric. Food Chem. 57(20):9427-9436

4. Elfalleh W, Tlili N, Nasri N, Yahia Y, Hannachi H, Chaira N, Ying $M$, Ferchichi A (2011): Antioxidant Capacities of Phenolic Compounds and Tocopherols from Tunisian Pomegranate (Punica granatum) Fruits. J. Food Sci. 76:707-713 
5. Kulisic, T., Radonic, A., Katalinic, V., Milos, M. (2004): Use of Different Methods for Testing Antioxidant Activity of Oregano Essential Oil, Elsevier Food Chemistry 85: 633-640, Croatia

6. Hassimotto, N. M. A., Genovese, I. S., \& Lajolo, F. M. (2005): Antioxidant activity of dietary fruits, vegetables, and commercial frozen fruit pulps. Journal of Agricultural and Food Chemistry, 53(8), 2928-2935
7. Rowe, R.C., Sheskey, P.J., Owen S.C. (2006): Handbook of Pharmaceutical Excipients, Fifth Edition, Pharmaceutical Press, London, 583 